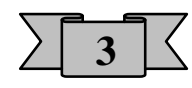

\title{
Sharia Police: Gender Discrimination, and Elite Politics in Aceh
}

\author{
Khairul Hasni \\ Ritsumeikan University, Kinugasa Kyoto Japan \\ hasni71@yahoo.com
}

\begin{abstract}
The first part of this paper will argue that under Shariah Law in Aceh the Shariah Police as an agency that implements the enforcement of Islamic law based on Law No.11 / 2006 on the Government of Aceh. There are several aspects which contribute to this systematic expansion of women which will be discussed in this paper. These aspects include the fulfillment of the Wilayatul Hisbah or Shariah Police body in the contribution of the implementation of the Qanun Jinayah, and more importantly, women get justice behavior both legally and practically towards the community. The second part of the paper will explore what is or rather what should be the gender discrimination in the interim of criminal law, and the number of violence was the increase from 2005 to 2019. Finally, it will discuss the possibility of overcoming these obstacles by giving greater consideration of the role of elite politic in the implementation of Shari Law in Aceh.
\end{abstract}

Bagian pertama dari naskah ini akan menyatakan bahwa di bawah Hukum Syariah di Aceh Polisi Syariah sebagai lembaga yang mengimplementasikan penegakan hukum Islam berdasarkan UU No.11/2006 tentang Pemerintah Aceh. Ada beberapa aspek yang berkontribusi pada ekspansi sistematis perempuan ini yang akan dibahas dalam makalah ini. Aspek-aspek ini termasuk pemenuhan Wilayatul Hisbah atau badan Kepolisian Syariah dalam kontribusi implementasi Qanun Jinayah, dan yang lebih penting, perempuan mendapatkan perilaku keadilan baik secara hukum maupun praktis terhadap masyarakat. Bagian kedua dari naskah ini akan mengeksplorasi apa yang seharusnya atau apa yang seharusnya menjadi diskriminasi gender untuk sementara hukum pidana, dan jumlah kekerasan meningkat dari 2005 hingga 2019. Akhirnya, ia akan membahas kemungkinan mengatasi hambatan-hambatan ini dengan memberikan pertimbangan yang lebih besar terhadap peran politik elit dalam penerapan Hukum Syariah di Aceh.

Keywords: Shariah Law, Shariah Police, Women, Discrimination. 


\section{INTRODUCTION}

A change in political direction in post-tsunami Aceh has conferred GAM the opportunity to participate in politics, and at the same time, the application of Sharia Law has experienced many post-conflict trials and challenges (Edward Aspinall, 2008).

The government of Aceh has accomodated the agreement through the enactment of Law No. 11/2006 on Aceh Government. In the Helsinki MoU, Aceh cauld form local parties, local political parties will be able to align with constituents in the regions more precisely given the diverse interests that are held by the people of Indonesia (Asda Rasida, 2016). From that point forward, the use of Sharia Law in Aceh has extended in the whole locale of Aceh and has blended with other social and legitimate customs. The extension of Sharia Law realizes conventional organizations to change into lawful foundations.

The role of the Indonesia in the implementation of Sharia Law in Aceh, the department of the Constitution of 1945 which honors the units of local government that are special Law No. 44/1999 on the implementation of the privileges of Aceh province, and Law No. 11/2006 on the Government of Aceh legally regulated the implementation of Sharia Law in Aceh. These laws served as a strong base to thoroughly enact Sharia Law in Aceh. Wilayatul Hisbah (WH), or better known as Shariah Police, have existed in the Sharia Law enforcement stipulated in the Decree of the Governor of Aceh since 2004. Based on various versions of the rule of the Law on the Governing of Aceh (LoGA) which has governed the Qanun Jinayah (Criminal Law), Sharia Police have had their respective systems in Islamic countries that impose Sharia Police. Aceh has the legality of using Sharia Police as part of the implementation of Sharia Law (Haryanto, 2014). The implementation of Sharia Law in Aceh is carried out under the authority of Sharia Law. Institution Aceh's Sharia Law office is tasked to design Qanun, implement and supervise the enforcement of Sharia Law, and to provide guidance on Sharia Law (Cut Maya Aprita Sari, 2017, Dinas Syariat Islam, 2018).

Furthermore procedural Sharia Law was since used as a justification to legitimize government policy and power. The long conflict with the government of the Republic of Indonesia also began with disappointment because the government did not give permission to authorized to implement Sharia Law in Aceh. Despite pros and cons of the internal community of Aceh itself to the conflict, the Acehnese people view the implementation of Sharia Law (the history of the Acehnese is often linked to the historical development of Islam in Aceh) as a story of the struggle to uphold the teachings of Islam (Siti Ikramatoun, 2016).

This article argues that the conceptual limits of the formal Sharia Law, process implementation sixteen years of LoGA, have been predominantly masculinist and have excluded Acehnese women's voices and experiences. This is reflected in the lack of women's involvement in the formal Sharia Law and then the creation of special autonomy and the coordination of political power-sharing within public sphere politics. These concerns are, of course, central to Aceh's future; however, the exclusive focus of the Sharia Law process on these issues short comings in the Qanun itself and their implementation created conforms to elite in the sense that it pursues only those political norms.

The stereotypical view of society towards women greatly influences not only the material but also the implementation of local regulations. As a result of these regulations, the citizens of Aceh suffer from discrimination, violence and the 
exploitation of women. (T. Saiful, 2016). Thus, the lack of government socialization of the implementation of Sharia Law in Aceh has resulted in violence against perpetrators who commit violations of Sharia Law (Kompas.com, 2013). In the implementation of regional regulations in Aceh the impact gained was so great because of differences in behavior towards women folk caused a sense of injustice and resulted in the seizure and practice of discriminating against women. (Muhammad Nasir, 2013)

Sharia Law was legalized and enforced in Aceh because it supported the sociocultural and historical society. Although Aceh was formerly known as a center for the spread of Islam in the archipelago, the implementation of the Shari Law in Aceh (T. Saiful, 2016). Sharia Law has been actualized in Aceh since 2001 when the region increased some independence in the wake of hitting an arrangement with the government in an offer to diminish pressure with rebels. Furthermore, the Aceh parliament in September 2014 passed the Aceh Islamic Criminal Code, a standing rule which criminalizes a scope of acts including same-sex, sexual movement, sex outside marriage and being distant from everyone else with somebody of the contrary sex who is not a marriage accomplice or relative. Those discovered liable could confront caning, detainment or fines forced by Islamic courts (news.com.au.asia, 2014).

Non-Government Organisation's (NGO) that are members of the Civil Society Network for Advocacy Qanun Jinayat stated this in Jakarta on Sunday (10/22), coinciding with the three-year ratification of the Qanun Jinayat. Human rights activists criticize the contents of the qanun because they are considered discriminatory and can increase violence against women (BBC, 2017). However, on the other hand, women are often the first victims of the formalization of Islamic Law. (Yusdani, 2006). The formalization of the Sharia also had implications for the position of women. But, the danger of discrimination against women that arises because of the formalization of Sharia Law is an unusual problem. Actually, one side of Sharia Law gives women equal status with men.

This discussion on Sharia Law has been widely discussed globally in a variety of Islamic or political literature, whether in the form of books or writings in the form of articles/papers, journals and others. Regarding the Aceh problem with the application of the Shariah, international literature is still minimal because this is still a development process and the first in Indonesian history. Previously the writings only described at a glance and globally. This means that it does not discuss in detail and in-depth how in the field of Sharia Police in the implementation of Sharia Law on the policies of the Aceh government with its various analyzes from every angle. Following in 2004 the foundation of the Sharia Police, these attacks turned out to progressively visit and correctional. Scopes by Sharia Police of prominent diversion and stimulation places, for example, shorelines, evening time bistros, inns and furthermore to target different infringement, particularly those concerning the vicinity of people, and liquor, betting and, less every now and again, non-cooperation in Friday supplications.

The Qanun Jinayah or (criminal law), the Shariah police, and the policy linkages of political parties in Aceh. There are two questions to be addressed in this paper. First, during the Sharia period of Islam, why do women experience discrimination and criminalization in the implementation of Qanun Jinayat? Second In the implementation, the Sharia Police is a very important institutional body for the implementation of Sharia Law in Aceh, 
The introduction above shows the Sharia Law, Qanun Jinayat, and Sharia Police. All three of these issues show that the Qanun Jinayat has discriminated against the women victims. This paper seeks to examine how the application of the Qanun Jinayat by Sharia Police discriminated against women.

\section{LITERATURE REVIEW}

In Indonesia, Aceh is the only area in the country with the formal legal recognition for Sharia concerning implementation of provincial privileges special region of Aceh. There several institutions have been established to support the implementation of Sharia Law and they include Sharia Court, Sharia Police, and the Sharia Islam Office (Dinas Sharia). The people of Aceh formally implement Sharia Law with the approval of the Indonesian central government. When the government set new Sharia Law rules, the public gives a good reaction to this policy (Siti Ikhramatoun, 2016, T. Saiful, 2016).

However, the Qanun that has been ratified, the majority of the Qanun material only regulates human private problems and ignores existing social realities such as poverty, education, health, and other social problems. The noble goal of public policy products is to bring prosperity and the common good (Cut Maya Afrina Sari, 2018). Moreover, there are several types of Qanun issued that are deemed not gender-responsive and often give unfair treatment to women's groups (T. Saiful, 2016).

The origins of the birth of Qanun through the legislative process in the Aceh House of Representatives (DPRA) are assisted by a team of various experts following the specified fields. This Qanun became the official law of Sharia Law in Aceh. As a result, implementing Qanun (law) in 23 districts and 5 cities is assisted by the Sharia police and prosecutors to conduct basic tasks and functions of law enforcement agencies (Kurniawan, 2012).

Qanun Jinayat (criminal law) has been officially implemented since 23 October, 2015 the Implementation of special feature of the special province of Aceh and Law No. 11/2006. This was possible due to the autonomy of the Aceh government to regulate its territory (Syamsul Bahri, 2013). Qanun which regulates the implementation of Sharia Law, even specifically for criminal (Qanun Jinayah) who have experienced unification makes the government and elites in Aceh become the main actors for the successful implementation of Sharia Law. According to Cut Maya Afrina Sari the existence of Qanun which was approved in 2006, the public policy rules have given feedback to the increasing support of the people of Aceh for the Jakarta government, (Cut Maya Afrina Sari, 2018). Besides, Sharia Law enforcement has given the impression that the issue of Sharia Law enforcement has been used as political interest in conflict conditions in Aceh.

Types of criminal and discussion Qanun No. 6/2014 concerning Qanun Jinayat was expanded. The Qanun is used to regulate a total of 10 criminal acts including, regulating maisir, khamar, and khalwat but also regulating ikhtilat (making out between two people who are not husband and wife), adultery, sexual harassment, qadzaf (accusing others of infidelity without evidence), liwath (homosexual), musahaqah, and rape (Cut Maya Afrina Sari 2018). However, there are specific errors observed in the delivery of judgment in Aceh due to damaging punishments given to crime victims. According to the statements from several NGOs in the Jakarta Legal Aid 
Foundation (YLBI) Jakarta, the provisions of Qanun Jinayat, the constitution and several laws, both in content and in the process of creating them have the potential for worsening violence and discrimination against women.

Furthermore, Qanun Jinayat is a unity of criminal law formed on Sharia Law values, and the Jarimah (crime) attracts a caning sentence, fine in the form of gold, or prison depends on the level of crime. In Aceh Qanun rules contain Sharia Law material included in the category of Qanun relating to the implementation of social life, (Nyak Fadhlullah, 2016). The formulation of legal norms in the Qanun Jinayah Legal also adopts the principles of the Koran and the Sunnah concerning crime (Nyak Fadhlullah, 2016).

Nevertheless, over the past ten years, the implementation of Sharia Law in Aceh has experienced many challenges and new experiences in the lives of the people of Aceh. They are giving birth to the dynamics of community perception in interpreting Sharia Law which functions to regulate the social and religious life of the community. In the implementation of Sharia Law, some people do not care about Sharia Law rules. Some still care about being critical in the actions of community organizations or NGOs (Siti Siti Ikramatoun, 2016). Besides, the Qanun Jinayat is listed as the most controversial in the community, not only in Aceh but also at the national and international level (Nyak Fadhlullah, 2017, Cut Maya Afrina Sari, 2018).

The Aceh government has socialized the application of Sharia Law to various corners, and the community has responded in multiple ways (T. Siaful: .258). The four points of criticism on the Sharia Law implementation are commonly voiced by Acehnese to be that: (1) The present Qanun is poorly written, the number of to vague guidelines which are subjected to arbitrary interpretation. (2) There have been few opportunities for citizens to participate in the process of developing the law. (3) Community socialization has been weak and left citizens with an unclear understanding of how Sharia Law functions. (4) The Qanun is mostly symbolic, attaching sanctions to private matters (such as dress or prayer) while ignoring more public severe offenses (Troy Johnsons, 20017).

\section{METHOD}

This research method focuses on describing the experience of the individual through descriptive to emphasizing more of the kind of field research. This study used semistructured interviews, focus groups, and participant observation. The location of this study is one area that uses sharia (Sharia Law) in everyday life of community. Data were obtained from the Sharia Police and NGOs and organizations under the government. In some cases, the experience was affected by the implementation of Sharia Law by Sharia Police in Aceh Indonesia. The results of the interviews were also analyzed manually, direct personal investigation of the author has to collect the information personally from the sources of the field concerned. Data analysis in this study is the analysis model, which is the simplest, data display and data verification and conclusion drawing. 


\section{FINDINGS AND DISCUSSION}

\section{Sharia Police Authority}

The implementation of Sharia Law in Aceh is carried out under the authority of the Office of Sharia Law in Aceh Province. This institution with designing the Qanun, implementing, supervising the implementation, and providing guidance on Sharia Law. The Sharia Office forms and appoints Sharia Police or Wilayatul Hisbah (WH) who are domiciled in the Sharia Police and who has to supervise Sharia Law (Cut Maya Afrina Sari, 2018). This institution also has to design, implement, monitor, and provide guidance on Sharia Law.

In order to strengthen the position of Sharia Police, Law. No. 11/2006 in Article 244 paragraph (2) was enacted after its existence has been established Law Number 44/1999 concerning the Implementation of the Privileges of the Special Region of Aceh Province and affirmed by Law Number 18/2001 concerning Special Autonomy for the Special Province of Aceh as the Province of Nanggroe Darussalam (Syarizal Abbas, 2015). The law enforcement agency was set up as part of the Civil Service Police Unit through Perda (regulation Qanun) No. 5/2000 as a body to monitor and reinforce Sharia. In addition, the main issue is about the certainty of the functional career path of a Sharia Police officer. At the provincial, regency or city level, the appointment is made by the Governor, Regent or Mayor while the Gampong or village level is by the officers of the Tuha Peut (Chairperson of the Village).

Sharia Police has around 6,300 members in Aceh (Human Right Watch, 2010) and its establishment is deemed necessary due to its usefulness in implementing Sharia Law through the use of Islamic approaches. The process of law enforcement and supervision of the implementation of Islamic Law is overseen by the Sharia Police being an institution tasked with the responsibilities of super vising, fostering, and advocating against the implementation of laws and regulations in Sharia Law (Muhammad Siddiq, Muhammad Zulhilmi, \& Ihdi Karim Makinara, 2015). However, the existence of this institution still has many problems both internal and external. The regulations have formed in the regional rules become part of the work of the Sharia Police, and operating funds still constrain some areas in its implementation.

The Sharia Police also handles some cases and have their authority overlapping with the National police. In situations where arrests, seizures, and searches made are not in accordance with procedures set forth in the Qanun Jinayat procedural law or in criminal law, the cases are audited, declared incomplete and returned to Sharia Police office by the Prosecutor's Office (Ria Delta, 2015). They are not covered by the national employment system and state administrative law, and this has led to uncertain functional career levels (Muhammad Siddiq, Muhammad Zulhilmi, \& Ihdi Karim Makinara, 2015).

Sharia Police act as implementers of Sharia Law and have the authority to provide protection to victims. It was further discovered that the since 2004 when it was founded, assaults and violence have been on the decrease. However, Hospi Novizal from Banda Aceh Legal Aid Institute revealed rape to be one of the serious crimes known to have been committed by Sharia Police.

Sharia police often conduct raids rather than socialization. The presence of Sharia Police only focuses on conducting operations in the context of implementing Islamic Sharia. The operation was carried out by monitoring the city, controlling the youth, 
and conducting raids in places deemed to violate the Sharia (Cut Maya Afrina Sari, 2018). The community helps in providing information about violations in the village environment. Places mostly found in places of excitement like shorelines, inns and evening time bistros and also target those engaged in betting and liquor, and, less as often as possible, non-investment in Friday petitions.

The case that occurred in Langsa City of the treatment of Sharia Police towards women:

(1) Tualang, Tengoh, Aceh. In the detention room, the woman was raped by 3 Sharia Police. According to the report from Langsa's general hospital, the result of the autopsy showed the victim had suffered sexual violence. (Rakyatku. news, December 26, 2017). Violence against the woman was perpetrated by Sharia Police, the perpetrators were punished with about12 years of jail time (Rakyatku.News, December 26, 2017).

(2) Another: case was a young girl, named Putri Erlina, from East Aceh who ended her life by committing a suicide on September 6th, 2012. It was allegedly caused by Sharia police's accusation that she was a sex worker. The victim, with a friend, was arrested by the Sharia police after watching a single organ event (Serambi Indonesia, 2012).

At reality the Sharia police's often discriminatory and violent law enforcement practices (Human Right Now, 2018). The abuse of power has led to protests from various parties and made the Sharia Police not get the trust of the people in the community. First implementing of Sharia part of Sharia Police, it was difficult for the Sharia Police to approach the society because of the authority of cases misuse of responsibility.

The Sharia Police have responded to conduct a strict fashion raid regularly against the public. Ironically, the community becomes a target of being examined and arrested while doing public transport activities or riding a motorcycle. However, people who drive privately are often ignored and checked and left to continue when the raid is being carried out. Women who wear clothing are not by the Sharia and do not wear the hijab, are arrested and given advice (Cut Maya Afita Sari, 2016). According to the head of the Banda Aceh Sharia Police who was driving the car, they were not arrested by Sharia Police because they did not show clothes of body. These have led to a different interpretation of the community; treatment was a form of discrimination against motorcycle riders.

In practice, the implementation of Sharia Law by the Sharia Police has not been effective and can be said to be "only a motto". It has been observed that awful cases, disconnection, betting, and drinking as well as nefarious activities in cafes, hotel, and other open places are still prevalent (Muzakkir, Hasballah Thaib, 2017). This can be associated with several challenges, especially with gender discrimination, faced by the Sharia Police in conducting their functions in the community. Furthermore, Qanun regulates limited moral issues and personal problems of individuals such as the prohibition of adultery, stealing, gambling, or khamar. As a result, Qanun is unable to solve community problems in social matters. Besides, there is no development of capacity skills in providing services, understanding gender, and international legal rules regarding The Convention on the Elimination of all Forms of Discrimination Against Women (CEDAW) and human rights. It can be seen in the position of Sharia 
Police who can not develop in a career path and often new violence against society, especially women.

\section{The Elite Politics and Local Party as Political Power}

After the Helsinki MoU between the Republic of Indonesia and GAM, the application of Sharia Law was formalized in the Law of the Republic of Indonesia Number 11/2006 is concerning Aceh Government and also the Qanun Aceh Number 6 of 2014 regarding Qanun Jinayat (Syamsuddin Bahrum, 2016). The Law has the authority to regulate various qanun/regional regulations, including in the field of justice (Muzakir Abubakar, Suhemi, Basri, 2011). The granting of the exclusive autonomy rights of Aceh and the Law on Regional Governance, since 1999 the adoption of regional regulations (Perda) has increased after the reform process (Erfina Fuadatul Khilmi, 2018).

The situation of political was changing in Aceh part of the involvement of local parties one of which is the Aceh Party (PA) is one of the local political parties formed by the Helsinki MoU with the Government of Indonesia. In 2008 the Aceh Party (PA), one of the local political parties that were established in Aceh in the 2009 legislative elections as a result of the verification of the Aceh Independent Election Commission (KIP). A new political transformation in Aceh was introducing, providing opportunities for individual candidates to nominate as governors, regents, and mayors in the regional elections (Pilkada). The political subject in building the province of Aceh became a kind of unification between GAM elites and civil society there through local political parties (Iwan Ismi Febriyanto, Wawan Edi Kuswandoro, Faza Dhora Nailufar, 2014).

The dynamics of local political parties in Aceh are right to turn GAM's armed struggle into a political battle through election and parliament (Syamsuddin Bahrum, 2016). The first election held in 2009 was won by the Aceh Party for the provincial level, reaching 33 seats out of a total of 69 seats (48\%) (Chairul Fahmi, 2014). Moreover, Aceh's local party is also a form of political expression for their disappointment in national legislative and policy conditions. As a result, the establishment of a new identity as a political subject in the people of Aceh was successfully carried out. Story politic in Aceh was one of the hegemonic forms of the Acehnese in responding to uneven national development, especially in the province of Aceh. (Iwan Ismi Febriyanto, Wawan Edi Kuswandoro, S.Sos, M.Si and Faza Dhora Nailufar, 2014).

In the application of Sharia Law, the Aceh Party (PA) faction in the Aceh House of Representatives (DPRA), together with the Aceh government, adopted the Aceh Qanun No. 6/2014 concerning Qanun Jinayat, which regulates laws regarding perpetrators of Jarimah (prohibited acts) (Syamsuddin Bahrum, 2016). The Aceh Party should carry out the values of Islamic teachings in the life of the nation and state. However, instead of as a reality on the ground in which the critical performing artists are individual Acehnese. GAM pioneers realize that for a significant number of their supporters, Sharia is essential (Edward Aspinall, 2007). The period of 10 years until the 2019 period controlled by local parties, namely the Aceh party in each regency, regional leaders led by PA.

Furthermore, during the rise of local political power after the enactment of the LoGA in Aceh, civil society lost control. Thus, along with the implementation of Sharia Law in Aceh policy actors representing parties in Aceh are still unable to make justice to the community and are still half-hearted in supporting Sharia Law in Aceh. The 
Governments to implementing Islamic Law that allocation budget that is five percent of the total Aceh Expenditure Budget or the Aceh Expenditure Budget (APBA) in 2017-2018 as Governor-General Regulation (serambinews. com, 2018). However, activities in the implementation of Sharia Law conducted by the Sharia Police minimized due to lack of funds, and this occurred in several areas in North Aceh and Lhokseumawe City.

Moreover, the dismissal of 900 Sharia Police is carried out by the local government because of the lack of budget in the 2018 Aceh Expenditure Budget (APBA). The regional head policy represented by local political parties won in the elections does not fully support the work of the Sharia Police. According to Otto Syamsuddin, one of the human rights activists, in a repressive context, the government is strengthening training, not by reducing personnel (BBC, 2018).

The government had established the Qanun Jinayah, one of the Qanuns that were guarded continuously by the Aceh government, which was given exclusive authority to the Sharia Police. Then followed by policies in several districts have issued regional regulations (Perda) that are more related to women's issues. However, at the implementation level, the formation of sharia regulations gave birth to debate and phenomenal when in the process of drafting, (Erfina Fuadatul Khilmi, 2018)

In Aceh some of the discourses of Perda that have become debates among the people of Aceh. First, in 2009, the Regent of West Aceh banned Muslim women in the district from wearing tight pants or jeans. The West Aceh government has provided unique skirts of various sizes for women who wear trousers. While the pants they were wearing out because many protests over the editing were only carried out at the beginning of surveillance of trousers for women. However, despite these regulations, some women still wear pants because they are more comfortable when riding a motorcycle.

Second, on 7 January 2013 Mayor Suaidi Yahya of Major Lhokseumawe Aceh, issued circular banning adult women from sitting astride. Lhokseumawe Mayor Suwaidi Yahya urged women not to sit astride when riding on a motorcycle. According to the mayor of women sitting astride when riding a bike, it is not following the Islamic culture of Aceh. According to various Lhokseumawe women activists, the regional policies of the mayor related to the rule of discrimination against women endanger women. It can cause accidents if women also carry goods and children while in a pillion and who use motorbikes from women are mostly from the lower level economy.

Third, the Major of Banda Aceh in 2015, the curfew rules for women in Banda Aceh city. Banda Aceh Mayor Illiza Sa'aduddin issued Instruction No. 1/2015 concerning the prohibition of women from working until midnight. This Perda was establishing is to protect female workers in certain places, such as coffee shops and other entertainment venues. It also protects young people from wandering around late at night. According to Illiza Sa'aduddin as ex-Mayor Banda Aceh city, that to the limitation for women working at 23.00 at night in Banda Aceh also protects female workers. However, the instruction has raised the attention of many communities and organizations, both local, national, and international. According to the Minister of Women's Empowerment and Child Protection Yohana Yambise the curfew for women in Banda Aceh is discriminatory. 
Fourth, Saifanur as the Bireun District Head of Aceh in 2018 issued a circular prohibited sitting one table of men and women in a coffee shop. The following Sharia Law, Bireuen Regent, passed a ban on coffee shops and restaurants that men and women to shit at one table, women prohibited from working over curfew.

Fifth, there is also the polygamy discourse for men in Aceh. Aceh government a new draft Perda contained polygamy rules design to protect of the rights Acehnese women this to reduce the divorce rate due to the high number of marriages. According to the National Commission on Violence Against Women (Komnas Perempuan) Aceh, Regional House of Representatives (DPRA) Perda try to discuss the issue of polygamy regulated in the National Law. The Aceh polygamy Qanun discourse controlled in Law No. 1 of 1974 concerning Marriage. However, the reason for the making of polygamy rules in Aceh is because of the rise in Siri marriages, so what should be corrected is the question of marriage registration. Qanun should strengthen the implementation of the law so that there are no violations of the law (Komnas Perempuan, 2019).

Sixth, July 10, 2019, women and children prohibited from going out at night in North Aceh of Regent Muhammad Thaib and organizations declared under 17 years is not allowed to come out at night. Furthermore, women are not allowed to go out at night without a husband or mahram. This task is under the authority of the Civil Service Police Unit (Satpol PP) and Sharia Police the North Aceh district government has placed around ten members of Sharia Police and Satpol PP each sub-district North Aceh.

The six Perda in the discourse and appeal part of the work by Sharia Police as Sharia Law implementing agencies that have placed in each regency and cities in Aceh. And that became part of the work of the Sharia Police, the more local regulations the duties and responsibilities of the Sharia Police increased. Sharia Police have limited member capacity, skills, and services, from various causes, there can be the potential for violence and discrimination against women. The process implementing of Sharia Law has happened of violations but an attitude of the government to respond to the abuses of Sharia Law is only as an offense. In this case, it is not making the experience of change for the future (Siti Ikratoun, 2016). The regional regulations on women are not balanced, so some indications do not involve women in the formation of that rule. The guiding principle is the principle in which the content of the legislation functions to protect marginal and minority groups (Erfina Fuadatul Khilmi, 2018). Nevertheless, The suspects in the implementation of the qanun are women and civil society who do not have political access and power.

\section{Women and Gender Experiences}

Muslims in Aceh wear Islamic clothing covering their aurat for men, the territory of the body from the knee to the navel, and ladies, the whole body except for the hands, feet, and face. Although the law applies to both sexes, there is undue attention and more stringent limitations on women. This condition part constitutes a more significant number of violators (Human Right Watch, 2010). The influence of changing clothes is more dominant to women than modern clothes changing Muslim costume. Besides, women who experience sexual violence also suffer negative stigma from the community (P2TP2 North Aceh, 2017). Therefore, it can be deduced that women and the poor have turned into the essential focus of authorization (ICC, 2006). 
According to the Office of Islamic Sharia (DSI), the violation of the Sharia is mostly related to Qanun 11/2002 and No. 14/2003. The provision governs the dressing code and vulgar behavior, especially with the majority of teenagers, caught dating or not wearing headscarves (for women) and offenders are punished by caning (yukepo. Indonesiaku, 2017). Nevertheless, data show of 234 women aged between 14 to 55 years old have experienced violence such as intimidation, beating, jailing, immersion, bathing with ditch water, forced marriage, and also sexual harassment in hijab raids and effectuation of Qanun Khalwat. This was experienced both individually and in groups (Komnas Perempuan, 2012). Furthemore, according to the National Commission on Violence Against Women, around 265 to 342 are discriminatory policies with 76 regulating dress code according to a single interpretation of religious teachings thereby limiting right to freedom of expression and religion. The Institute of Criminal Justice Reform (ICJR) noted that there were 339 decisions of Qanun Jinayat dropped by the Aceh Sharia Court between early 2015 and December 2016. The regions that mostly issued discriminatory policies were West Java, West Sumatra, South Sulawesi, Aceh, South Kalimantan, South Sumatra and East Java (Indonesia, 2013).

Regarding the problem of Aceh, the Civil Society Network for the Advocacy of the Qanun Jinayat Jakarta reported its content are in contrary to the Constitution and a number of laws, both in substance and the process of its formation. It was also observed that the Islamic Law has the potential to create violence and discrimination against women in the province. However, a member of the National party of the Aceh PKS (Partai Keadilan Sejahtera) faction, Tgk Makhyaruddin Yusuf, revealed that the implementation of Sharia Law in the province was not discriminatory against gender and adherents of other religions (republika.co.id 2012). It was further noted that most arrests or raids conducted were on women riding motorbikes, sex workers, salons and LGBT.

In the field of law, the affirmation of female subordination often occurs, and it has been discovered that of the laws of Indonesia are unable role towards women. This indication proves that a gender imbalance is still prevalent in the country, and this was shown to be apparent in the content, culture, and structure of law. Thus, in the legal, cultural aspect, it is still strongly influenced by patriarchal values which get strong legitimacy from religious interpretation. Religion is also caused by being an element perpetuating the patriarchal culture and gender imbalance in the field of law (T. Saiful, 2016). The problem when women experience violence is that little cares about their situation, and instead, they are considered the cause of the incident. In this case, it is very little chance for women to be able to fight for themselves because the body and behavior continue to be controlled by the state with various regulations that suppress women's lives.

The local government of Aceh has socialized the application of Sharia Law to various corners and the community responded in various ways. The community needs better the implementation would help them in overcoming all their problems (Yudani, 2016). However, the Sharia Police is also very weak in providing services and religious knowledge of women's rights in the community. As an example of seeing the case of Sharia Police often commit violations while on the field and also often get resistance with the community. 


\section{CONCLUSION}

Aceh is at a unique crossroad in its history in various struggles namely Islam, war and peace. The challenge for Aceh now, in its first decade after a period of peace, is to transform that Sharia Law into one that will move beyond the absence of civil war and include the presence of gender justice. In order for this to occur, the politics of reconstruction and recovery must include the reconstruction of equitable gendered social relations within the Acehnese context, and women's experiences as a central tenet in both the history and future of Aceh's. However, in the implementation in the field, it has caused new violence both discrimination of women and people accused of committing violations. This, in turn, has highlighted the breadth of the woman challenges facing implementation Sharia Law but has also pointed to the contribution that both women and men might make to pursuing enduring of justice.

This Implementation of Sharia Law is reflected only by elite masculinist agenda that either sidelined women. Sharia Police as a tool in implementing Sharia Islam still requires understanding in serving women and society. Ignoring their diversity and their capacity to build Sharia Law from the ground up, the formal Shariah Law pursued a top-down agenda political power. The failure to ensure that women, and issues specific to women, were represented throughout the Sharia Law indicates gendered, and problematic, conceptualization of Sharia.

And this has become a literacy that took place over a period of 13 years when Sharia Law was imposed on political interest. From the results of a strong analysis, in the financing of the budget for the implementation of Sharia Islam by the Sharia Police, which has been approved by $5 \%$ of the local funds, the reality in the field of Shariah Police could not work optimally because it does not fulfill the finances both in the field operations and caning.

Regarding the attitude of the Sharia Police in implementing the qanun, it is necessary to implement it better and more selective member selection system that understands religion. A good recruitment system is needed so that it has implications for the quality of qanun implementers who can give good value to the community. Improving the performance of implementers must be supported by high government commitment so that the Sharia Police can develop more in understanding gender and providing good services to the community.

\section{REFERENCES}

[1] Asda Rasida, Suharso, Habib Mukhsin, (2016). Partai Politik Lokal Aceh Dalam Sistem Ketatanegaraan Republik Indonesia, 8.

[2] Cut Maya Aprita Sari, 2017. Pro dan Kontra Implementasi Qanun Syariat Islam di Aceh, https://www.researchgate.net/publication/327666087_Pro_dan_Kontra_Implemen tasi_Qanun_Syariat_Islam_di_Aceh

[3] Chairul Fahmi, (2104). Prilaku Politik Pada Demokrasi Transisi: Studi kasus di Provinsi Aceh pada Pemilu 2014, Aceh Institute Banda Aceh, Indonesia, 221.

[4] Edward Aspinall, 2007, The Politic of Islamic Law in Aceh, Association for Asian Studies Annual Meeting 2007, March 22-25, Boston, 29. 
[5] Erfina Fuadatul Khilmi, 2018. Pembentukan Peraturan Daerah Syari'ah dalam Perspektif Hukum Tata Negara Pascareformasi, Lentera Hukum, Volume 5 Issue 1 (2018).

[6] Haryanto, (2014). Polisi Syariah: Keamanan untuk Siapa?, Jurnal Ilmu Sosial dan Ilmu Politik, 170.

[7] Indonesia, (2013). Komnas Perempuan: Ada 342 Perda Diskriminatif di Indonesia https://www.voaindonesia.com/a/komnas-perempuan-ada-342-perdadiskriminatif-di-indonesia/1736465.html

[8] Iwan Ismi Febriyanto, Wawan Edi Kuswandoro, S.Sos, M.Si dan Faza Dhora Nailufar, (2014). Partai Politik Lokal Aceh Dalam Perspektif Demokrasi Radikal, https://www.academia.edu/8857250/Partai_Politik_Lokal_Aceh_Dalam_Perspekti f_Demokrasi_Radikal Fisip Universitas Brawijaya. 13.

[9] Kurniawan, (2012). Dinamika Formalisasi Syari'at Islam Di Indonesia, The Dynamics Of Formalization Of Islamic L America aw In Indonesia, Kanun Jurnal Ilmu Hukum, 435.

[10] Muhammad Siddiq, Muhammad Zulhilmi, \& Ihdi Karim Makinara, (2015). Posisi Kedudukan Wilayatul Hisbah Dalam Birokrasi Pemerintah Aceh: Studi terhadap jabatan fungsional Wilayatul HisbahUniversitas Islam Negeri Ar-Raniry Banda Aceh, Indonesia, Conference Proceedings - ARICIS I.

[11] Muhammad Nasir, (2013). Syariat Islam Dan Ngangkang Style: Mengenal Kearifan Lokal dan Identitas Perempuan Aceh, Fakultas Adab IAIN Ar-Raniry, 202.

[12] Muzakkir, Hasballah Thaib, (2017). Implementation of Law in Aceh After Application Qanun Jinayah International Journal of Humanities and Social Science Invention, 3.

[13] Nyak Fadhlullah, (2017). Metode Perumusan Qanun Jinayah Aceh: Kajian Terhadap Pasal 33 tentang Zina, IN RIGHT, 16

[14] Nazamuddin, Agussabi, and Syamsuddin Mahmud, (2010). Economic Modernization and influence on the Social Sytem in Aceh, Aceh History, Politic and Culture, Institute of Southeast Asian Studies (ISEAS), Singapore.

[15] Ria Delta, (2015). Kewenangan Wilayatul Hisbah Dalam Proses Penanganan Perkara Pidana Qanun, 9.

[16] Syamsuddin Bahrum, (2016). DINAMIKA PARTAI POLITIK LOKAL (Analisis Partai Aceh dan Penerapan Syari'at Islam) Pascasarjana Universitas Islam Negeri Sumatera Utara, 143-144.

[17] Siti Ikramatoun (2016). Respon Masyarakat Aceh Terhadap AturanDan Implementasi Syariat Islam Pasca Tsunami, Prodi Sosiologi, Fakultas Ilmu Sosial Dan Politik, Universitas Syah Kuala,Aceh, Sosiologi Reflektif, 3-4.

[18] Syahrizal Abbas, MA, (2015). Qanun Aceh Nomor 6 Tahun 2014 Tentang Hukum Jinayat, Dinas Syariat Islam Aceh.

[19] Syamsul Bahri, (2013). Konsep Implementasi Syari'at Islam Di Aceh Sharia Law Implementation Concept In AcehKonsep Implementasi Syariat Islam di Aceh, Kanun Jurnal Ilmu Hukum No. 60, Th. XV (Agustus, 2013), pp. 313-337.

[20] Samsul Bahri, (2017). Wilayatul Hisbah dan Syariat Islam di Aceh: Tinjauan Wewenang dan Legalitas Hukum, Jurnal Syariah, 12.

[21] Troy Johnsons, (2007). "Voice from Aceh: Perspective on Syariat Law," Working Paper Seriers . No. 97, Southeast Asia Research Center (SEARC).

[22] T. Saiful, (2016). Gender Perspektif dalam Formalisasi Syariat Islam di Aceh Kanun, Fakultas Hukum Universitas Syiah Kuala, Jurnal Ilmu Hukum, 248. 
43 Al-Hayat: Journal of Islamic Education (AJIE)

e-ISSN: 2599-3046 (online) | Volume 4, Issue 1 | January - June 2020

p-ISSN: 2657-1781 (print)

[23] Tim Diskusi di Komnas Perempuan, (2012). Catatan Dua Tahun Terakhir (20112012), Kekerasan terhadap Perempuan di Aceh Menjelujur Pengalaman Kekerasan Perempuan di Aceh Perjuangan Tiada Henti Meniti Keadilan.

[24] Yusdani, (2006). Formalisasi Syariat Islam Dan Hak Asasi Manusia Di Indonesia, Al-Mawarid. 